\title{
The Triplaria tree (Triplaris spp) and Pseudomyrmex ants: a symbiotic relationship with risks of attack for humans
}

\author{
Pau-de-novato (Triplaris spp) e formigas Pseudomyrmex: uma relação \\ simbiótica com riscos para seres humanos
}

\author{
Vidal Haddad Junior ${ }^{1}$, Luiz Roberto Hernandes Bicudo ${ }^{2}$ and Adílson Fransozo ${ }^{3}$
}

\begin{abstract}
The authors report a massive attack by Pseudomyrmex ants on a human who touched a Triplaria - novice tree (Triplaris spp). The ants naturally live in these trees and their stings cause intense pain and discrete to moderate local inflammation. The problem is common in some Brazilian regions and can be prevented by identifying the trees.
\end{abstract}

Key-words: Ants. Trees. Venomous animals.

\section{RESUMO}

É descrito um ataque maciço de formigas do gênero Pseudomyrmex a um humano que tocou uma árvore-de-novato (Triplaris spp). As formigas vivem naturalmente nestas árvores e as picadas causam dor intensa e inflamação local. 0 problema é comum em certas regiões do Brasil e pode ser prevenido pela identificação das árvores.

Palavras-chaves: Formigas. Árvores. Animais peçonhentos.

One of the more interesting associations between animals and plants is the symbiosis between various tree genera and ants of the Pseudomyrmex and Azteca genera. This kind of relationship is not rare in nature: many ant species can live in hollow trunks and branches of trees, protecting the plant and using the place as secure cover ${ }^{12}$. Numerous descriptions exist of Azteca genus ants living in Cecropia trees (trumpet trees) in South American countries, including Colombia, Costa Rica and Brazil: the Cecropia tree and Azteca ant relationship is one of the most conspicuous of all ant-plant associations in Costa Rica. The hollow tree trunk and the production of food bodies rich in glycogen, attract the Azteca ants onto the Cecropia trees. The ants are said to protect the trees from herbivores and prevent creepers growing ${ }^{2}$. The tree-ant association is believed to be symbiotic, a variation of mutualism where two organisms from different species interact to their mutual advantage ${ }^{212}$. The Cecropia provides food and shelter for the ants, while the ants protect the trees, which also receive nitrogen from ant carcasses ${ }^{8}$. The level to which ants provide protection is still unknown. In North and Central America, the acacia tree (Acacia cornigera) has colonies of stinging ants (Pseudomyrmex ferruginea) which occupy the

1. Botucatu School of Medicine, São Paulo State University, São Paulo, SP, Brazil. 2. Department of Botany, Institute of Biosciences, Botucatu, SP, Brazil. 3. Department of Zoology, Institute of Biosciences, Botucatu, SP, Brazil.

Address to: Dr. Vidal Haddad Junior. Caixa Postal 557, 18618-000 Botucatu, SP, Brazil.

Telefax: 55 14 3882-4922

e-mail: haddadjr@fmb.unesp.br

Received in 19/06/2009

Accepted in 19/11/2009 hollowed-out thorns and fiercely defend the tree against ravaging insects, browsing mammals and epiphytic vines ${ }^{1}$.

In Brazil, groups of trees can be found that have ants living in inside them: the embauba (hollow tree in the Brazilian Indian language) is a popular name for the very common Cecropia tree. Azteca genus ants can be observed in this and other trees; however, the most important symbiosis is between Pseudomyrmex ants and the Triplaria tree.

Pseudomyrmex ants (novice ants) live in cavities of the trunk and branches of the novice tree, the pau-de-novato (Triplaris spp). The names novice ants and novice tree are associated with the fact that only those new to the region touch these trees, due to attacks by the ants.

Triplaris americana is the most common species of novice tree. It is a large, beautiful tree (10-20m high) that has a hollow trunk and branches. Its popular names are pau-formiga or pau-de-formiga (ant tree), pau-de-novato (novice tree), formigueiro (ant mound) and taxizeiro ${ }^{10}$.

The novice ants (formigas-de-novato, tachi or taxi) belong to the order Hymenoptera, family Formicidae and genus Pseudomyrmex. They vary in diameter and color, but most of them are yellow (Figure 1, 2 and 3). They have a thin body and large compound eyes. One characteristic of these ants is the double knot in their abdomen. Kempf proposed Pseudomyrmex triplarinus as the main species living in trees of the Triplaridae family.

Pseudomyrmex ants can inflict a very painful sting from venom injected by a non-barbed stinger located in their abdomen. Studies on Pseudomyrmex triplarinus venom have revealed 12 proteins with molecular weights of 100,000-4,200 Da and compared to 


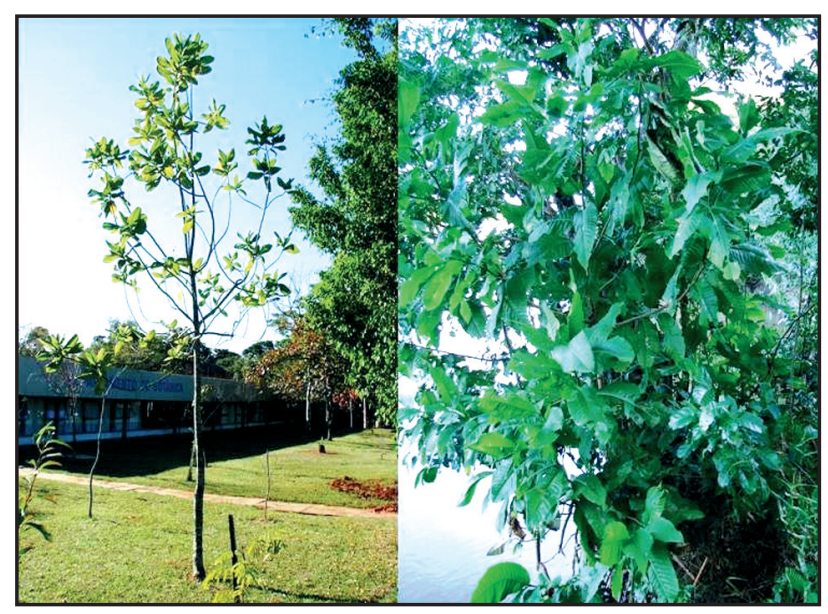

FIGURE 1

The novice tree (Triplaris spp); the image on the left is the tree that was associated with the victim's injuries.

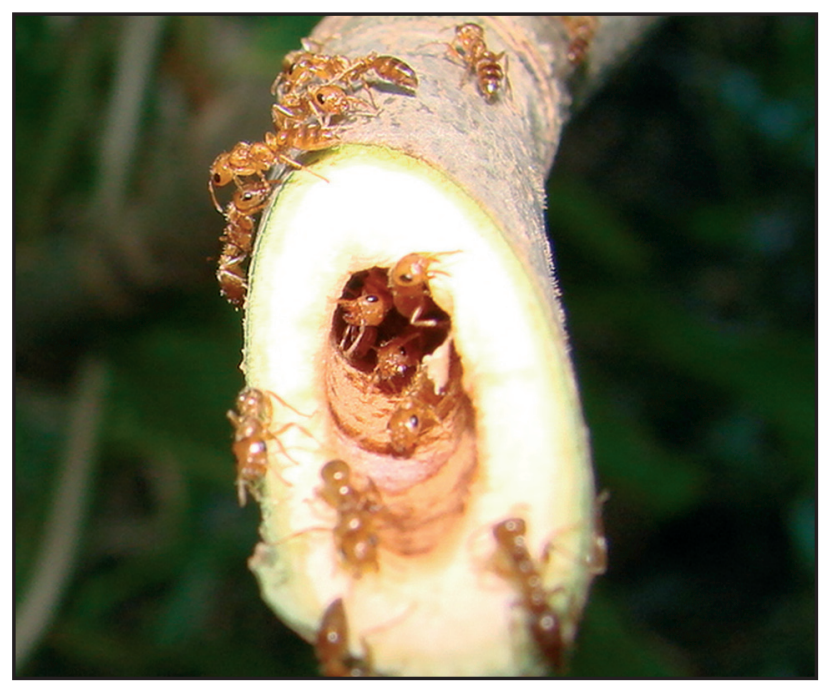

FIGURE 2.

Novice tree ants (Pseudomyrmex triplarinus) attack after the cutting of a branch of the tree.

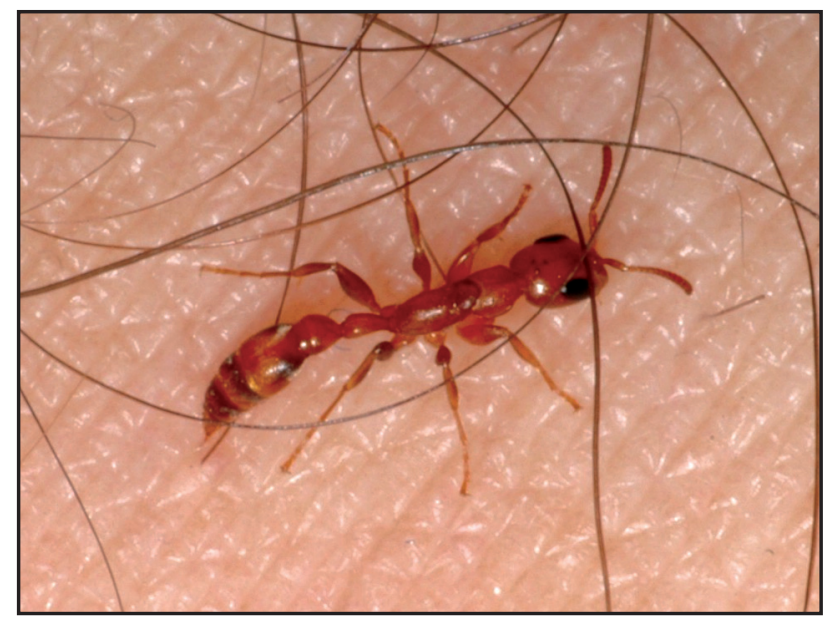

FIGURE 3

A close view of the Pseudomyrmex triplarinus, the novice tree ant. published data on ant, wasp and bee venoms, their whole venom has intense phospholipase activity and intermediate hemolytic activity $^{7}$. The venom also has antiinflammatory properties with a multiprotein complex that inhibits edema and contains six pure proteins designated myrmexin I-VI. This suggests that myrmexins may represent a new class of antiinflammatory proteins ${ }^{11}$.

\section{CASE REPORT}

The patient, a white 52 year-old male, was a tourist in the town of Miranda, in the Pantanal region of Mato Grosso do Sul, Midwest Brazil. During a boat trip on the Miranda River, he lifted and broke a tree branch at the edge of the river so the boat could reach the margin. Immediately a group of yellow ants viciously attacked his arm. The victim suffered nearly 50 stings that provoked instantaneous intense pain. Moderate edema could be seen at the sting penetration sites (Figure 4). The patient presented intense sweating, agitation and tachycardia without other arrhythmias, but arterial pressure was normal. He was given analgesic (oral dipyrone); however, this did not relieve the pain, which persisted for approximately eight hours. The next morning, no pain or local inflammatory manifestations were observed at the sting sites.

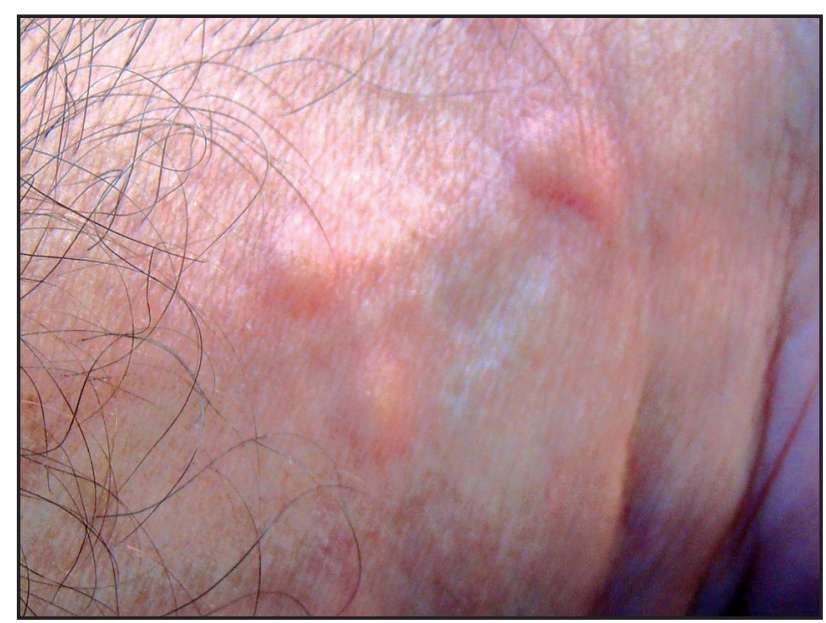

FIGURE 4

Local edematous papules and inflammation after a massive attack of novice tree ants.

\section{DISCUSSION}

Pseudomyrmex ants are venomous insects that furiously defend their hiding place. When someone touches the Triplaris tree, a great number of ants attack the intruder. In addition to attacking the part in contact with the tree, the ants spread over the body causing new stings and curious reactions from victims who can jump in the water or take off their clothes due to the pain and perception of crawling ants. This kind of accident is common in tourists and other strangers to such regions.

The pain is very intense with no relief from oral analgesics. The pain only fades after nearly eight hours. Due to the intensity of the pain, we suspected the establishment of marked local inflammatory manifestations, but different to other ant stings, 
such as the Solenopsis invicta species (red fire ants), no important edema, pustules or surrounding inflammation were observed $^{345}$. The Ponerinae family consists of very venomous ants, such as the tocandira ants (Paraponera clavata) ${ }^{6}$, and envenomation by Ponerinae ants is severe, with excruciating pain causing instantaneous adenopathy, while provoking discrete local manifestations. The mechanism of envenomation is venom glands linked to a stinger in the abdomen, an apparatus common to venomous ants. The effects of the venom are mainly due to phospholipase activity, similar to other Hymenoptera, and manifest with intense pain and discrete to moderate edema.

In conclusion, novice ants (formigas-de-novato or tachi) are classified in the Pseudomyrmex genus.

The Pseudomyrmex ants viciously attack anything that touches the trees. The stings are very painful and the systemic manifestations are probably associated with the intense pain. New research is required to more fully determine the habits of the ants, potential treatments and venom composition.

\section{REFERENCES}

1. Acacia Trees. Wayne's word. Available in: http://waynesword.palomar.edu/acacia. htm. Accessed in April, 30, 2009.

2. Agrawal AA, Dubin-Thaler BJ. Induced Responses to herbivore in the Neotropical antplant association between Azteca ants and Cecropia trees: responses of ants to potential inducing clues. Journal of Behavior, Ecology and Sociobiology 45: 47-54, 1999.

3. Conceição LG, Haddad Jr V, Loures FH. Pustular dermatosis caused by fire ant (Solenopsis invicta) stings in a dog. Veterinary Dermatology 17: 453-455, 2006
4. Haddad Jr V. Acidentes por formigas (Accidents caused by ants). In: Cardoso JLC, França FOS, Wen FH, Malaque CMS, Haddad Jr V (orgs.). Animais peçonhentos no Brasil: biologia, clínica e terapêutica dos acidentes (Brazilian venomous animals: biology, clinics and therapheutic aspects of the accidents). Editora Sarvier, São Paulo, p.252-257, 2003.

5. Haddad Jr V, Cardoso JLC, França FOS, Wen FH. Acidentes provocados por formigas: um problema dermatológico (Accidents caused by ants: a dermatological problem). Anais Brasileiros de Dermatologia 71: 527-530, 1996.

6. Haddad Jr V, Cardoso JLC, Moraes, RHP. Description of an injury in a human caused by a false tocandira (Dinoponera gigantea, Perty, 1883) with a revision on folkloric, pharmacological and clinical aspects of the giant ants of the genera Paraponera and Dinoponera (sub-family Ponerinae). Revista do Instituto de Medicina Tropical de São Paulo 37: 235-238, 2005.

7. Hink WF, Pappas PW, Jaworski DC. Partial characterization of the venom from the ant Pseudomyrmex triplarina. Toxicon 32:763-372, 1994.

8. JRScience. Cecropia trees and Azteca ants. Available in: http://jrscience.wcp. muohio.edu/fieldcourses01/PapersCostaRicaArticles/CecropiatreesandAztecaant. html. Accessed in April, 30, 2009.

9. Kempf WW. Estudos sobre Pseudomyrmex. III. Studia Entomológica 4: 369-408,1961.

10. Lorenzi H. Arvores brasileiras: manual de identificação e cultivo de plantas arbóreas nativas do Brasil (Brazilian native trees: a handbook of identification and cultive). Plantarum, Nova Odessa, 1998.

11. Pan J, Hink WF. Isolation and characterization of myrmexins, six isoforms of venom proteins with anti-inflammatory activity from the tropical ant, Pseudomyrmex triplarinus. Toxicon 38: 1403-1413, 2000.

12. Pseudomyrmex ants. INSECTA TV. Available in: http://images.google.com. br/imgres?imgurl=http://br.geocities.com/insecta_tv/Pseudomyrmex001. jpg\&imgrefurl=http://br.geocities.com/insecta_tv/glossario.html\&usg= toXySdNeLVc-IVvrwgJzfAkDi8=\&h=416\&w=1333\&sz=39\&hl=pt-BR\&start=10\& tbnid=VgOly9BeWwN51M:\&tbnh=47\&tbnw=150\&prev=/images\%3Fq\%3Dpaude-novato\%2B\%252B\%2Bformigas\%26gbv\%3D2\%26hl\%3Dpt-BR. Accessed in April, 29, 2009. 